\title{
Evaluation of platelet and mean platelet volume levels in patients with liver cirrhosis
}

\author{
Karaciğer sirozlu hastalarda platelet ve ortalama platelet hacmi düzeylerinin değerlendirilmesi
}

\section{Mustafa Genco Erdem ${ }^{1}$, Eylem Özgün Çil ${ }^{2}$, Tufan Tükek ${ }^{2}$, Şerife Ayşen Helvacı ${ }^{3}$}

\begin{abstract}
Aim: Liver cirrhosis isa process characterized by fibrosis and normal liver structure is replaced with diffuse nodular structure. Different laboratory values are used for diagnosis and prognosis of liver cirrhosis. To determine platelet and mean platelet volume levels of patients with liver cirrhosis and to find out if platelet or mean platelet volume levels have changed according to Child-Pugh classification or the etiology of cirrhosis Methods: A total of 201 patients with cirrhosis who have been followed by of an education and research hospital internal medicine out-patient clinic between the years of 2006 and 2013, were included. Platelet count $<150,000$ / $\mu \mathrm{L}$ was accepted as thrombocytopenia. Individuals with diseases that can cause thrombocytopenia, patients using drugs that can cause thrombocytopenia and who has pseudothrombocytopenia were excluded from the study.

Results: The number percantage ratios of patients according to underlying etiology for chronic liver disease were as follows Group 1 (alcoholic liver disease) with rate of \% 16.9, Group 2 (hepatitis - B) with rate of \% 25.4, Group 3 (hepatitis - C) with rate of $\% 23.4$, Group 4 (cryptogenic) with rate of $\%$ 34.3.Average platelet value in the Group 1 was $130.2 \pm 74 \times 103 / \mu \mathrm{L}$, Group 2 was $104.8 \pm 56.8 \times 103 / \mu \mathrm{L}$, Group 3 was $100.6 \pm 44.2$ x 103/ $\mu \mathrm{L}$, Group 4 was 104,1 \pm 48.7 x 103/ $\mu \mathrm{L}$;average platelet value in the control group (Group 5) was 247.7 $\pm 58.7 \times 103 / \mu \mathrm{L}$. Average mean platelet volume values in the Group 1 was $9.19 \pm 1.32 \mathrm{fL}$, Group2 was $9.21 \pm$ $1.57 \mathrm{fL}$, Group 3 was $8.67 \pm 1.25 \mathrm{fL}$, Group 4 was $8.85 \pm 1.21 \mathrm{fL}$; average mean platelet volume value in the Group 5 was $8.05 \pm 1 \mathrm{fL}$.

Conclusion: In this study, platelet levels of the cirrhotic patients were lower than the control group's platelet levels; MPV levels of the patients with cirrhosis were higher than the control group's mean platelet volume levels. Platelet and MPV values were not different according to Child-Pugh stage or cirrhosis etiology. Therefore, more and larger scaled studies are needed to clarify conflicting conclusions about the impact of platelet number and MPV on chronic liver inflammation.
\end{abstract}

Keywords: Cirrhosis, mean platelet volume, platelet, thrombocytopenia

\section{Öz}

Amaç: Karaciğer sirozu, fibrozis ile karakterize ve normal karaciğer yapısının diffüz nodül yapısıyla yer değiştirdiği bir süreçtir. Karaciğer sirozunun tanı ve prognoz öngörüsünde farklı laboratuvar değerler kullanılmaktadır. Karaciğer sirozlu hastalarda platelet ve ortalama platelet hacmi düzeylerini saptamak; platelet veya ortalama platelet hacmi düzeylerinin Child-Pugh sınıflamasına veya siroz etiyolojisine göre değişip değişmediğini görmektir.

Yöntemler: Bir eğitim ve araştırma hastanesi iç hastalıkları kliniklerinde 2006 - 2013 yılları arasında yatışı yapılmış veya iç hastalıkları polikliniklerinde takibi yapılmış 201 karaciğer sirozlu hasta, vaka grubuna dâhi edildi. Platelet sayısı $<150000 / \mu$ olması halinde trombositopeni olarak kabul edildi. Trombositopeni yapabilecek hastalığı olanlar, trombositopeni yapabilecek ilaç kullananlar ve psödotrombositopenik hastalar çalışma dışı bırakıldı.

Bulgular: Vakalar etiyolojik nedenlerine göre gruplandırıldığında yüzdelik dağılımlar: Grup 1 (alkolik karaciğer hastalığı kökenli siroz olguları) \% 16,9, Grup 2 (hepatit - B kökenli siroz olguları) \% 25,4, Grup 3 (hepatit - C kökenli siroz olguları) \% 23,4, Grup 4 (Kriptojenik siroz olguları) \% 34,3 olarak bulundu. Çalışmadaki farklı sirotik etiyolojilerden oluşan dört grubun ortalama platelet değerleri Grup 1 için 130,2 \pm 74 x 103 / mikrolitre $(\mu \mathrm{L})$, Grup 2 için 104,8 $\pm 56,8 \times 103$ / $\mu \mathrm{L}$, Grup 3 için 100,6 \pm 44,2 x 103 / $\mu \mathrm{L}$ ve Grup 4 için 104,1 $\pm 48,7$ x $103 / \mu \mathrm{L}$ olarak hesaplandi. Kontrol grubundaki (Grup 5) ortalama platelet değeri ise $247,7 \pm 58,7 \times 103 / \mu \mathrm{L}$ idi. Gruplardaki ortalama platelet hacmi değerleri Grup 1 için $9,19 \pm 1,32$ femtolitre (fL), Grup 2 için $9,21 \pm$ $1,57 \mathrm{fL}$, Grup 3 için $8,67 \pm 1,25 \mathrm{fL}$ ve Grup 4 için $8,85 \pm 1,21 \mathrm{fL}$ olarak saptandı; 5 . Gruptaki ortalama platelet hacmi değeri ise $8,05 \pm 1 \mathrm{fL}$ idi.

Sonuç: Çalışmada sirotik hastalarda platelet değerleri, kontrol grubundan düşük; ortalama platelet hacm değerleri ise kontrol grubundan yüksek saptandı. Platelet ve ortalama platelet hacmi değerleri, Child-Pugh evresi ya da siroz etiyolojisine göre farklı saptanmadı. Bu nedenle, trombosit sayısı ve MPV'nin kronik karaciğer inflamasyonu üzerindeki etkileri hakkında çelişkili sonuçları netleştirmek için daha geniş ölçekli çalışmalara ihtiyaç vardır

Anahtar Kelimeler: Siroz, ortalama trombosit hacmi, trombosit, trombositopeni
1 Fatih Medical Park Hospital, Internal Medicine Clinic, Istanbul, Turkey.

Okmeydanı Training and Research Hospital, Internal Medicine Clinic, Istanbul, Turkey.

${ }^{3}$ Department of Internal Medicine, Biruni University Faculty of Medicine, Istanbul, Turkey.

This study was originated from the thesis with the same title by Mustafa Genco Erdem. Bu çalısma Dr. Mustafa Genco Erdem tarafindan aynı isimle yapılan uzmanlık tezinden türetilmiştir.

Ethics Committee Approval: The study was approved by the local ethics committee (18.07.2013).

Etik Kurul Onamı: Çalışmanın lokal etik kurul tarafından onaylanmıştır (18.07.2013).

Conflict of Interest: No conflict of interest was declared by the authors.

Çıkar Çatışması: Yazarlar çıkar çatışması bildirmemişlerdir

Financial Disclosure: The authors declared that this case has received no financial support.

Finansal Destek: Yazarlar bu olgu için finansal destek almadıklarını beyan etmişlerdir.

Geliș Tarihi / Received: 05.02.2018

Kabul Tarihi / Accepted: 15.02.2018

Yayın Tarihi / Published: 20.02.2018

Sorumlu yazar / Corresponding author Mustafa Genco Erdem

Adres/Address: Fatih Medicalpark Hospital Iskenderpasa Mah. Horhor Cad. No: 4 Fatih, Istanbul,--Turkey.

e-Mail: m.gencoerdem@gmail.com

Copyright (C) ACEM 


\section{Introduction}

The World Health Organization has described liver cirrhosis as a process characterized by fibrosis and displacement of the normal liver structure by diffuse nodule structure [1]. In etiology, the most common cause in developing countries and our country is chronic viral hepatitis; the most common causes in the United States of America are alcoholic liver disease and hepatitis $\mathrm{C}$ virus (HCV) [1]. The clinical basis is mainly the result of two major events: hepatocellular injury and portal hypertension. Cirrhotic patients have abnormalities in platelet number and function. Approximately $15-70 \%$ of cirrhotic patients have a platelet count below 100,000 / mm3 [2]. Platelet levels are also used as prognostic markers in cirrhotic patients [3].

Mean platelet volume (MPV) is a parameter measured in whole blood count analysis [4]; it is compatible with platelet function and activation [5-6]. Some studies have shown that MPV is a reflection of both proinflammatory and prothrombotic events. The intensity of systemic inflammation is a distinct factor in differentiating conditions associated with circulating large and small size platelets [7]. MPV has been associated with cardiometabolic risk factors such as obesity, hypercholesterolemia, diabetes, hypertension, and arterial stiffness [8-12].

In this study, it was aimed to determine platelet and MPV levels in patients with liver cirrhosis and to determine their association with Child-Pugh classification or cirrhosis etiology.

\section{Material and methods}

The ethical committee approval of this retrospective study was taken from the local ethics committee. This study has been conducted by the declaration of Helsinki. Informed consent could not be taken from the patients due to the retrospective design of the study.

Patients who had been admitted to internal medicine out-patient clinics between 2006 and 2013 or who had been followed up at the outpatient clinics of internal medicine; and patients whose etiology of cirrhosis were the alcoholic liver disease (Group 1), hepatitis-B (Group 2), hepatitis-C (Group 3) and cryptogenic (Group 4) were included in the study. Other etiologies of cirrhosis like autoimmune hepatitis $(n=5)$, cardiac cirrhosis $(n=4)$, hydatid cyst $(n=2)$, primary biliary cirrhosis $(n$ $=2)$, Budd- Chiari syndrome $(n=1)$, Wilson's disease $(n=1)$ were excluded from the study. The files of the patients were retrospectively scanned. A total of 201 patients (72 females, 129 males) were included in the four groups of patients with cirrhosis; a total of 100 patients (52 women, 48 men) were included in the control group (group 5). Patients who were admitted to internal medicine out-patient clinic with complaint of abdominal pain and who could not be diagnosed as a chronic disease as a result of the evaluation were taken into the control group according to the order of application.

Table 1: Age, sex, platelet count and MPV values of the study groups

\begin{tabular}{|c|c|c|c|c|c|c|}
\hline Parameter & Group 1 & Group 2 & Group 3 & Group 4 & Group 5 & $\mathrm{p}$ \\
\hline $\mathrm{n}$ & 34 & 51 & 47 & 69 & 100 & \\
\hline $\operatorname{Sex} \mathrm{f} / \mathrm{m}$ & $33 / 1$ & $29 / 22$ & $24 / 23$ & $43 / 26$ & $52 / 48$ & 0.0001 \\
\hline $\mathrm{MPV}^{¥}(\mathrm{fl})$ & $9.2 \pm 1.3$ & $9.2 \pm 1.6$ & $8.7 \pm 1.3$ & $8.9 \pm 1.2$ & $8.1 \pm 1$ & 0.0001 \\
\hline
\end{tabular}

Anamnesis (patient's age and gender, history of hepatitis and alcoholism regarding cirrhosis etiology of the patient, current chronic diseases, possible causes of thrombocytopenia, history of chemotherapy in the last six months) and laboratory data (platelet count and MPV) were taken into consideration. For Child-Pugh score and classification, encephalopathy and acid presence and their grades were used. The total score was 5-6 in the Child-Pugh group A; 7-9 in the Child-Pugh group B; and 10-15 in the Child-Pugh group C. Thrombocytopenia was accepted if the platelet count was $<150000 / \mu \mathrm{L}$. Patients who had diseases which can lead to thrombocytopenia; those who use drugs that could do thrombocytopenia; pseudothrombocytopenic patients and those whose data are missing were excluded from the study.

Arithmetic mean, standard deviation, median, minimum, maximum, ratio and frequency values are used in the descriptive statistics of the data. ANOVA and Kruskal Wallis tests were used for multiple group analysis. In the case of meaningful outcomes, the Post Hoc Tukey test was used to determine the groups from which the significance was derived. Pearson correlation test was used for correlation analysis. The statistical significance level was accepted as $\mathrm{p} \leq 0.05$ in all analyzes. SPSS for Windows 21.0 statistical package program was used.

\section{Results}

When patients are grouped according to their etiology of cirrhosis; group 1 alcoholic liver disease $(n=34, \% 16.9)$; group 2 hepatitis-B $(n=51, \% 25.3)$, group 3 hepatitis-C $(n=47$, $\% 23.3)$, group 4 cryptogenic patients $(n=69, \% 34.3)$. A total of 201 (72 females, 129 males) patients were included in the four groups of the patients with cirrhosis; a total of 100 participants (52 females, 48 males) were included in the group 5 (control group) (Table 1). The age range of cirrhotic patients included in the study ranged from 25 to 93 years; control group's ages vary between 54 and 71 years.

When age groups were examined, there was a significant difference between the groups. This difference was between group 1 and group $3(\mathrm{p}=0.0001)$, group 1 and group 4 $(\mathrm{p}=0.019)$, group 2 and group $3(\mathrm{p}=0.002)$, and group 3 and group $5(\mathrm{p}=0.0001)$ (Table.1)

When the groups were examined regarding gender, the gender distribution of the patients in group 1 was significantly different from that of the other groups $(\mathrm{p}=0.001, \mathrm{p}=0.0001, \mathrm{p}$ $=0.005$ and $\mathrm{p}=0.0001$, respectively) (Table 1$)$.

When platelet counts and MPV values were examined, platelet counts and MPV values of groups 1, 2, 3, and 4 did not differ significantly ( $p>0.05$ for all). However, there was a significant difference in the platelet count and MPV value between these four groups (Group 1-4) and Group 5 (Table 2).

There was no significant difference between platelet counts and MPV values in all three groups ( $p>0.05$ for all) (Table 3) after the categorization of patients with cirrhosis according to the Child-Pugh classification. the patient's albumin, INR and bilirubin values, hepatic

$8.7 \pm 1.3$

$8.9 \pm 1.2$

0.0001

${ }^{\ddagger}:$ mean \pm standard deviation 
Table 2: Comparison of platelet and MPV values between Group 5 and Groups 1-4.

\begin{tabular}{|c|c|c|c|c|c|c|c|c|c|}
\hline Parameter & Group 5 & Group 1 & $\mathrm{p}^{\mathrm{a}}$ & Group 2 & $\mathrm{p}^{\mathrm{b}}$ & Group 3 & $\mathrm{p}^{\mathrm{c}}$ & Group 4 & $\mathrm{p}^{\mathrm{d}}$ \\
\hline Platelet $^{*}\left(\mathrm{x} 10^{3} / \mu \mathrm{L}\right)$ & $247.7 \pm 58.7$ & $130.2 \pm 74$ & 0.0001 & $104.8 \pm 56.8$ & 0.0001 & $100.6 \pm 44.2$ & 0.0001 & $104.1 \pm 48.7$ & 0.0001 \\
\hline $\mathrm{MPV}^{\ddagger}(\mathrm{fL})$ & $8.1 \pm 1$ & $9.2 \pm 1.3$ & 0.0001 & $9.2 \pm 1.6$ & 0.0001 & $8.67 \pm 1.3$ & 0.042 & $8.9 \pm 1.2$ & 0.0001 \\
\hline
\end{tabular}

Group 4.

Table 3: Platelet and MPV values of groups according to Child - Pugh classification

\begin{tabular}{l|ccc} 
Parameter & Child-Pugh A & Child-Pugh B & Child-Pugh C \\
\hline Number & 18 & 87 & 96 \\
Platelet $^{\ddagger}\left(\mathrm{x} 10^{3} / \mu \mathrm{L}\right)$ & $117.0 \pm 57.3$ & $112.5 \pm 53.1$ & $102.5 \pm 57.3$ \\
MPV $^{\ddagger}(\mathrm{fL})$ & $9.4 \pm 1.2$ & $8.8 \pm 1.2$ & $9.0 \pm 1.5$
\end{tabular}

$¥:$ mean \pm standard deviation

\section{Discussion}

In cirrhotic patients, platelet life is reduced, platelet counts decrease, and abnormalities in their function appear [2, 13]. Platelet levels are also used as prognostic markers in cirrhotic patients [3]. MPV is compatible with platelet function and activation [5-6]. Studies have shown that MPV is a reflection of both proinflammatory and prothrombotic events. MPV is reduced in cases where peripheral platelet degradation is increased, and where platelet production is impaired [14-16]. In hypersplenism, which is an exception to this rule, low MPV is detected because large platelets are caught and destroyed in the spleen.

When the etiology of cirrhotic patients examined in this study; cryptogenic cirrhosis was the largest group with 69 patients $(30.9 \%)$, hepatitis - B acquired number of cirrhosis patients $51(22.9 \%)$, hepatitis - C acquired number of liver cirrhosis patients $47(21.1 \%)$ and alcoholic liver disease 34 cases $(15.2 \%)$ were observed. When these results are examined, it can be concluded that a total of 98 patients $(48.7 \%)$ were reached with the evaluation of viral hepatitis together and it is the most frequent etiological cause. This result is in line with studies of viral hepatitis in the first place in the cirrhosis etiology in developing countries [1]. Probably the reason for a large number of cases of cryptogenic cirrhosis was that the hospital where the study was conducted was one of the reference units in the gastroenterology field of Marmara region between 2006 and 2013. In addition, cases without a diagnosis were directed to this hospital for further examination. All but one of the cases of alcoholic liver disease is male, and this is compatible with the work of Corrao, who shares the knowledge that heavy consumption of alcohol is predominantly male gender specific [17]. However, it should be kept in mind that cirrhosis and similar outcomes are more likely to occur in women with severe alcohol consumption [18-20].

Thrombocytopenia is typical of cirrhotic patients, and it is one of the most sensitive and specific laboratory findings supporting cirrhosis. The first reason for the fall in platelet counts in circulation is the splenomegaly secondary to portal hypertension, the second is the immunologic breakdown of the platelets, and the third is the reduction in the production of hepatic thrombopoietin. In the study, the mean platelet count of cirrhotic patients was found to be thrombocytopenic and lower than the control group, regardless of etiology; this value was consistent with thrombocytopenic outcomes detected in similar studies of cirrhotic patients $[1,2,13,21]$.
The detection of thrombocytopenia in cirrhotic patients has three basic clinical significances: First of all, fibrosis score may be an advanced stage, cause if the fibrosis score increases, the number of platelets decreases; hence thrombocytopenia is a parameter that predicts fibrosis [22]. Second, the patient may have large esophageal varices. Especially when the number of platelets falls below $68,000 / \mathrm{mm} 3$, the sensitivity of detecting large esophagus varices increases to $71 \%$ and specificity to $73 \%$ [23]. Finally, thrombocytopenia may be a sign of poor prognosis; In studies conducted by Realdi et al, platelet level was found to be an independent parameter affecting the life span [3].

One of the remarkable features of the study was that the mean MPV of each group was significantly higher than the mean MPV of the control group regardless of cirrhosis etiology. This result was consistent with previous studies on chronic liver diseases, in which the increase in MPV value was correlated with inflammation [24-26].Also the results of recent studies by Kurt and Qi are compatible with our data [27-28]. In some previous studies, MPV was found to be lower in patients with hypersplenism than in the control group, and this has been shown to cause from spleen's destruction of large volumed platelets by holding them [21, 29]. The existence of two conflicting outcomes is an indication of the need for more and larger scaled studies in this area.

In comparison with cirrhosis etiology, the highest mean platelet value among the groups was found in the alcoholic liver disease group, but the difference between the groups was not statistically significant. When the mean MPV values were examined, the highest MPV value was found in patients with cirrhosis due to viral hepatitis - B and the lowest value was found in patients with cirrhosis due to viral hepatitis - C, but this difference was not statistically significant; which is consistent with the work of Giannini EG et al. [30].

Again, all cirrhotic patients in the study were grouped according to the Child-Pugh classification which used to evaluate the prognosis of cirrhosis regardless of their etiology; each group was compared with the other groups regarding mean platelet and MPV values. There were no significant differences between the groups, although there are studies that show the platelet value in cirrhotic patients is inversely proportional to the severity of the cirrhosis disease [3, 13]. There was no statistically significant difference between the MPV values of the Child-Pugh groups in accordance with the literature [30].

In conclusion, viral hepatitis and alcoholic liver disease were found to be most commonly etiology of cirrhosis patients in a manner consistent with developing countries. Also, thrombocytopenia was frequently observed in cirrhotic patients. Therefore, in the presence of thrombocytopenia in the full blood count, liver cirrhosis should be considered; viral hepatitis and alcoholism history must be questioned.

The mean MPV values of cirrhotic patients in the study were higher than the control group. There are conflicting conclusions about the possibility that chronic liver inflammation may be correlated with MPV value in previous studies, therefore more and larger scaled studies are needed in this area.

\section{References}

1. Heidelbaugh JJ, Bruderly M. Cirrhosis and chronic liver failure: part I. Diagnosis and evaluation. Am Fam Physician 2006; 74: 756-62.

2. Martin TG 3rd, Somberg KA, Meng YG, Cohen RL, Heid CA, de Sauvage FJ et al. Thrombopoietin levels in patients with cirrhosis 
before and after orthotopic liver transplantation. Ann Intern Med 1997; 127: $285-8$

3. Realdi G, Fattovich G, Hadziyannis S, Schalm SW, Almasio P, Sanchez-Tapias J et al. Survival and prognostic factors in 366 patients with compansated cirrhosis type B: a multicenter study. J Hepatol 1994; 21: 656-66.

4. Bath PM, Butterworth RJ. Platelet size: Measurement, physiology and vascular disease. Blood Coagul Fibrinolysis 1996; 7: 157-61.

5. Endler G, Klimesch A, Sunder-Plassmann H, Schillinger M, Exner M, Mannhalter $\mathrm{C}$ et al. Mean platelet volume is an independent risk factor for myocardial infarction but not for coronary artery disease. Br J Haematol 2002; 117: 399-404.

6. Kapsoritakis AN, Koukourakis MI, Sfiridaki A, Potamianos SP, Kosmadaki MG, Koutroubakis IE et al. Mean platelet volume: a useful marker of inflammatory bowel disease activity. Am J Gastroenterol 2001; 96: 776-81.

7. Gasparyan AY, Ayvazyan L, Mikhailidis DP, Kitas GD. Mean platelet volume: A link between thrombosis and inflammation? Curr Pharm Des 2011; 17: 47-58

8. Arslan N, Makay B. Mean platelet volume in obese adolescents with nonalcoholic fatty liver disease. J Pediatr Endocrinol Metab 2010; 23: 807-13.

9. Pathansali R, Smith N, Bath P. Altered megakaryocyte-platelet haemostatic axis in hypercholesterolaemia. Platelets 2001; 12: 292-7.

10. Papanas N, Symeonidis G, Maltezos E, Mavridis G, Karavageli E, Vosnakidis Tet al. Mean platelet volume in patients with type 2 diabetes mellitus. Platelets 2004; 15: 475-8.

11. Nadar S, Blann AD, Lip GY. Platelet morphology and plasma indices of platelet activation in essential hypertension: Effects of amlodipinebased antihypertensive therapy. Ann Med 2004; 36: 552-7.

12. Wang RT, Li Y, Zhu XY, Zhang YN. Increased mean platelet volume is associated with arterial stiffness. Platelets 2012; 22: 447-51.

13. Qamar AA, Grace ND, Groszmann RJ, Garcia-Tsao G, Bosch J, Burroughs AK et al.Incidence, prevalence, and clinical significance of abnormal hematologic indices in compensated cirrhosis. Clin Gastroenterol Hepatol 2009; 7: 689.

14. Dow RB. The Clinical and laboratory utility of trombosit volume parameters. J Med Sci 1994; 15: 1-15.

15. Bancroft AJ, Abel EW, Mclaren M, Belch JJ. Mean trombosit volume is a useful parameter: a reproducible routine method using a modified Coulter Thrombocytometer. Trombosits 2000; 11: 379-87.

16. Şenaran H, İleri M, Altınbaş A, Koşar A, Yetkin E, Özturk M. et al. Thrombopoietin and mean trombosit volume in coronary artery disease. Clin Cardiol 2001; 24: 405-8

17. Corrao G. Liver cirrhosis mortality trends in Eastern Europe, 19701989. Analyses of age, period and cohort effects and of latency with alcohol consumption. Addiction Biol 1998; 3: 413-22.

18. Ikejima K, Enomoto N, Iimuro Y, Ikejima A, Fang D, Xu J et al. Estrogen increases sensitivity of Kupffer cells to endotoxin. Am J Physiol 1998; 274: G669-76.

19. Reed T, Page WF, Viken RJ, Christian JC. Genetic predisposition to organ-specific endpoints of alcoholism. Alcohol Clin Exp Res 1996; 20: $1528-33$.

20. Colantoni A, Idilman R, De Maria N, La Paglia N, Belmonte J, Wezeman $\mathrm{F}$ et al. Hepatic apoptosis and proliferation in male and female rats fed alcohol: Role of cytokines. Alcoholism: Clin Expl Res 2003; 27: 1184-9.

21. Jorgensen B, Fischer E, Ingeberg S, Hollaender N, Ring-Larsen H, Henriksen JH. Decreased blood platelet volume and count in patients with liver disease. Scand J Gastroenterol 1984; 19: 492-6.

22. Adinolfi LE, Giordano MG, Andreana A, Tripodi MF, Utili R, Cesaro $\mathrm{G}$ et al. Hepatic fibrosis play a central role in the pathogenesis of thrombocytopenia in patients with chronic viral hepatitis. $\mathrm{Br} \mathrm{J}$ Hematol 2001; 113: 290-5.

23. Madhotra R, Mulcahy HE, Willner I, Reuben A.Prediction of esophageal varices in patients with cirrhosis. J Clin Gastroenterol 2002; 34: 81-5.

24. Uslu AU, Aydın B, Balta S, Yonem O, Uncu T, Seven D. The effect of standard therapy on mean platelet volume in patients with chronic hepatitis C. Prz Gastroenterol 2016; 11: 200-5.

25. Hu Y, Lou Y, Chen Y, Mao W. Evaluation of mean platelet volume in patients with hepatitis B virus infection. Int J Clin Exp Med 2014; 7: 4207-13.

26. Purnak T, Olmez S, Torun S, Efe C, Say1lır A, Özaslan E et al. Mean platelet volume is increased in chronic hepatitis $\mathrm{C}$ patients with advanced fibrosis. Clin Res Hepatol Gastroenterol 2103; 37: 41-6.

27. Kurt M, Onal IK, Sayılır AY, Beyazıt Y, Öztaşş E, Kekilli M et al. The role of mean platelet volume in the diagnosis of hepatocellular carcinoma in patients with chronic liver disease. Hepatogastroenterology 2012; 59: 1580-2.

28. Qi XT, Wan F, Lou Y, Ye B, Wu D. The mean platelet volume is a potential biomarker for cirrhosis in chronic hepatitis B virus infected patients. Hepatogastroenterology. 2014;61:456-459.

29. Karpatkin S, Freedman ML. Hypersplenic Thrombocytopenia Differentiated From Increased Peripheral Destruction by Platelet Volume. Ann Int Med. 1978;89:200.

30. Giannini EG, Moscatelli A, Brunacci M, Zentilin P, Savarino V. Prognostic role of mean platelet volume in patients with cirrhosis. Dig Liver Dis. 2016;48:409-413. 